\title{
A Study of the Present Condition and Causes of Decay of Nawankot Monument, Lahore
}

\author{
A.M. Malik, M.Y.Awan, and M. Rashid
}

\begin{abstract}
Nawankot monument is an important part of the heritage of the Mughal architecture. The heritage of any country is its identity. The dilemma at this time is that this heritage is been deteriorated with the passage of time due to our negligence. This paper identifies the causes of decay and deterioration of the Nawankot Monument. The objective is to put forward the recommendations to save this precious heritage.

Nawankot Monument, 369 years old gateway structure went through the same deterioration since its construction, it has gone through some maintenance procedures, though never under ample conservation plan being negligence on the Government part.

This paper is focused on the study and analysis of the present condition of the monument structure situated at Multan Road, Lahore. A complete assessment of the structure shows that there is no single factor responsible for the deterioration and decay of Nawankot Monument. It has been found that there are number of internal as well as external factors responsible for decay of the monument. This paper is an effort to promote the development of a comprehensive restoration plan by providing necessary information required for the conservation/restoration of this historical monument.
\end{abstract}

Keywords-Mughal architecture; Cultural heritage; Monument; Archaeology; decay; deterioration; destruction; restoration; neglect; maintenance; façade.

\section{INTRODUCTION}

Nawankot Monument is comprised of an entrance gateway structure and two isolated turrets, of the tomb garden of the princess Zeb-un-Nisa. Nawankot Monument is situated almost at the spot where Nawankot locality is now situated at Multan Road, Lahore. Princess Zeb-un-Nisa was one of the daughters of Emperor AurangZeb. She died in 1080 A.H. (1669 A.D). The tomb garden of Zeb-un-Nsa was decorated with marvelous pishtaq (Gate way) building and other summer houses. This beautiful complex was constructed in 1056 A.H (1646 A.D). But Ranjit Singh disadvantaged the building of all its valuable material and used it in his summer house (Marble Baradari) at HazuriBagh, in front of the Badshahi Mosque Lahore. Now there are not found any traces of the garden and the building attached to it exist except an old gate way pishtaq

Manuscript received May. 30, 2016. This work was supported by School of Architecture and Planning, University of Management and Technology, Lahore, Pakistan.

A.M. Malik (Assistant Professor) (Corresponding Author) is with the School of Architecture and Planning, University of Management and Technology, Lahore, Pakistan.

M. Y. Awan (Professor) is with the School of Architecture and Planning, University of Management and Technology, Lahore, Pakistan.

M. Rashid (Assistant Professor) is with the School of Architecture and Planning, University of Management and Technology, Lahore, Pakistan. and two disconnected turrets. This three centered double arched gateway was constructed in brick cut work. It is almost entirely covered with kashikari (Enameled Mosaic tile work) in blue green, orange and yellow. The interior is richly decorated with fresco paintings in red and green. The form of this gateway follows the standard design prevalent at the time, but the parapet is decorated with stylized merinos and chatius (umbrella shaped structures) on all four corners of the main gate Building. The remaining two turrets are originally of single height They are octagonal in plan each having a beautiful terra cotta molding on its projected bands at a height of 10 feet. After this height a pedestal of 12 inches with small square and rectangular panels give a base to the airy kiosks or Chattris. This Chatri has eight multifold decorated a riches-framed in rectangular depressed panels. It is surmounted by a small ribbed golden dome or cupola.

\section{MATERIALS AND METHODS}

The material on the renowned historic structure of the Nawankot Monument was collected from the primary and secondary sources of historic literature. It was further verified by examination of the structure on site. Numerous visits were carried out for close examination though detailed observation. Thus the collected material was analyzed with reference to its architectural composition of horizontal as well as vertical arrangements and ornamentation in its interior and exterior. The origin and roots of architecture and decoration were also traced out with the help of historic literature and also by considering the comparison with the similar structures build during the Mughal period.

\section{RESULTS AND DISCUSSION}

Through a thorough study the academic research the results reveals that there hasn't been done any serious conservation or restoration work for this monument that has thrown it years back being the negligence of the department of archeology. The Nawankot monument is one of the work of art of the Mughal architecture. In need to develop an appropriate plan for its restoration it is of utter importance to find the root cause of its deterioration over the years. Once done only then these problems can be addressed systematically.

This monumental gateway erected under royal benefaction and is a standard example of Mughal architecture. Construction showing extra ordinary achievements in the building art \& craft displayed in a classical manner. It is a symbol of gateways to walled gardens with embellishment in glazed mosaic (kashakari), fresco painting (nakashi), catalectic (galibkari) and decorative brick work (mamari) . Some of the serious causes of 
decay investigated are firstly the factors related to geographical location of building, such as thermal variation, rain and humidity and natural epidemics. Secondly the factors related to nature of ground/ flooding. Deterioration caused due to man-made factors like Obstinate Damage, neglect, air pollution, tremors, vandalism and no mature conservation adoption and lastly the deterioration caused due to Organic and fungus causes. These factors are explained as follow:

\section{A. Deterioration Causes Due to Geographical Location of the monument}

One of the natural and most effecting factors that can cause the deterioration or wear and tear are the factor affiliated with the climatic changes as per geography of the monument e.g., solar radiation, temperature, humidity, rain, wind speed, floods, earthquake etc.

\section{a. Thermal Variation}

Starting off with thermal effect first of all, Lahore comes in the extreme climate zone with maximum temperature of $48^{\circ} \mathrm{c}$ in summers and to $0^{\circ} \mathrm{c}$. The buildings go through certain thermal expansion due to the extreme weather change yet different used materials have different expansion and contraction due to the cracks caused as a result. The Nawankot monument is immense masonry construction. Both vertical and horizontal thermal movements have caused cracks throughout the upper and lower parts of the structure. The facade which is ornamented with different colored stones known as Kashi-Kari , has also developed cracks on its surface, yet exposed brick still lies in tact beneath this kasha-kari and can be seen, yet through these cracks the rainwater penetrates and causes damage to the interior of building, having fresco painting and Ghalib Kari work.

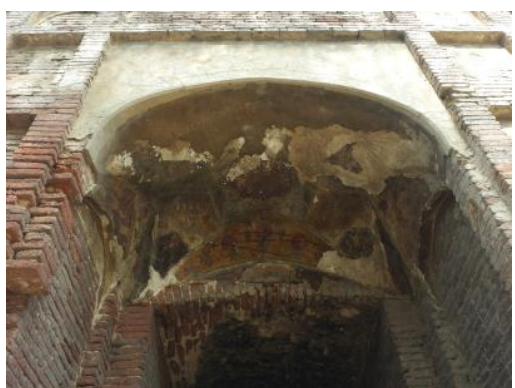

Fig. 1 View of the pishtaq entrance showing cracks

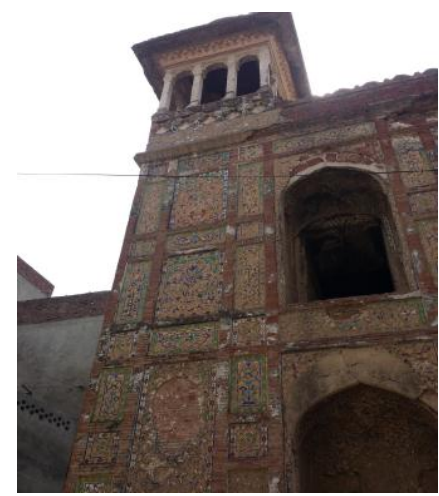

Fig. 2 Another View of the full

\section{b. Rain and Humidity}

The annual average rainfall of Lahore is 20 inches. Rain damages the brickwork above the ground and causes permeation of rainwater through capillary action ends up into the deterioration of structure internally as well. The rainwater is a combination of other soluble materials that causes damaging manifestation when this rainwater vaporizes. Salt crystallization results in powdering of surface again causing cracks in material used for construction also resulting into contour scaling due to this continuous chain of wetting and drying cycle of the monument.

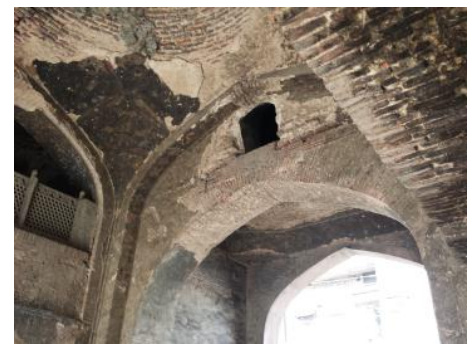

Fig. 3 Scaling seen inside the ghalibkari

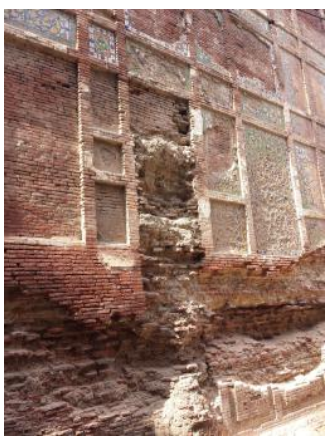

Fig. 4 Contour scaling seen on the façade

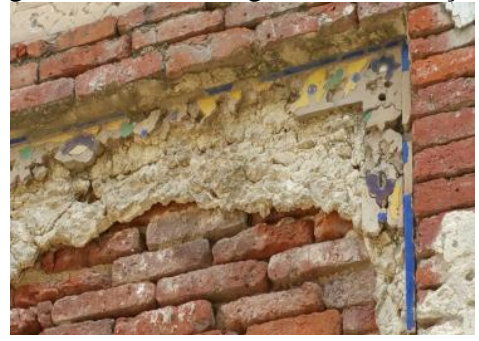

Fig. 5 Scaling seen inside the ghalibkari

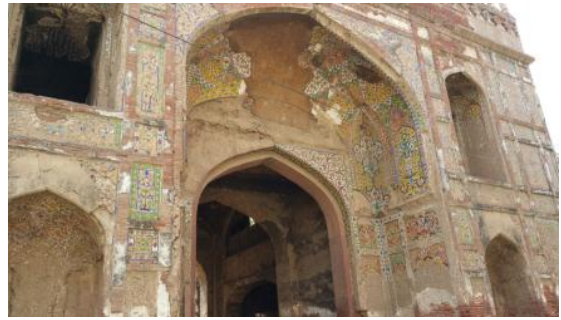

Fig. 6 Massive contour scaling noticed on the front facade

\section{B. Deterioration Causes due to Nature of Ground/Flooding}

The soil stability and nature of the ground is of utmost value as it determines the structural stability of the built monument also judged by the water- bed, salt, and nature of soil beneath the ground. Cracks in the massive and great constructions are also 
noticed when the load transmitted by the foundation is not balanced with the bearing capacity of the soil.

Now this monumental memento is in depression as compared to other stocks in the surroundings. The existing drain on the northern site is at higher site which is mostly blocked and over flooded especially during the rainy season, the water is accumulated at the ground and it remains there for weeks and months without any attention or intention to clear that area out even knowing the diseases spreading due to this unhealthy situation thus rising of the water table is a threat for structural stability of the monument, as it has changed the characteristics and behavior of subsoil . A continuous water level rise is noticed in the water table during the rains throughout the year thus making this dampness a continuous feature of the monument. This dampness itself is the most dangerous enemy of the monument as the continuous water effects each material in its own way thus effecting its strength and cohesive nature. The soil salts also mixes up with the lime mortar thus resulting in severe collapse of masonry joints with the growth of lichens, fungi and bacteria throughout in the structure, which has blackened the stone surface and disfigured it as well.

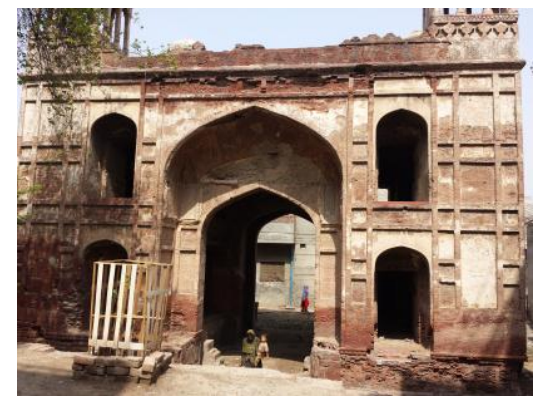

Fig. 7 Scaling seen inside the ghalibkari

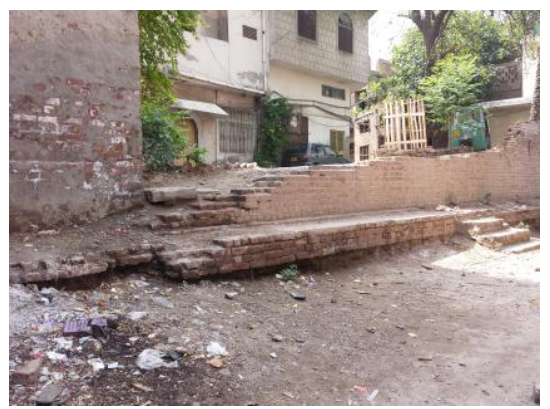

Fig. 8 Massive contour scaling noticed on the front facade

\section{Deterioration Causes due to manmade reasons}

Humans are capable of creating master pieces and destroying landmarks simultaneously. These defects are not only complex but has long lasting consequences. These are usually triggered by the side effects of industrialization, urban sprawl and population spread burden.

\section{a. Obstinate Damage}

It was one of the most beautiful gardens of Lahore in its time, decorated with costly stones and furnished with pavilions, fountains and water reservoirs whose khiyabans (walk-ways) bad geometric patterns in marble and stone. During the Ranjit Singh's rule, this garden was so badly treated, that its fountains in white marbles and walkways were removed in order to develop a resident scheme where everything was sold out and only the mausoleum remained. Ranjit Singh also stripped of the white marble and lattice windows from the tomb structure which were used in construction of his Baradari in Hazuri Bagh.

\section{b. Neglect}

As per senior Architect Kamil Khan Mumtaz abandoning and ignoring these master pieces of our old heritage are perhaps the major factors of destruction by humans themselves. Other issues such as social, economic, political and administrative etc are the underlying causes of neglect. Due to abandoned building, the care and maintenance was never there. In fact there is no life in it, with the result that the building has deteriorated to some extent although there are localities all filled with people living around yet they use this monumental structure not as a legend like it was known to be in history but as a junk disposal slot. Traces of birds' nests, feathers, blood have been found in the building along with other incomplete stories of illegal activities due to abandonment of this structure.

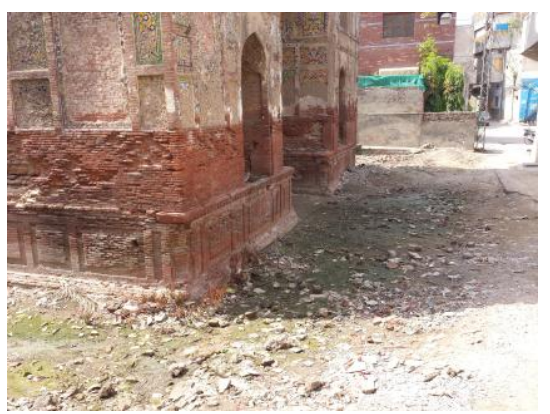

Fig. 9 Scaling seen inside the kashi kari

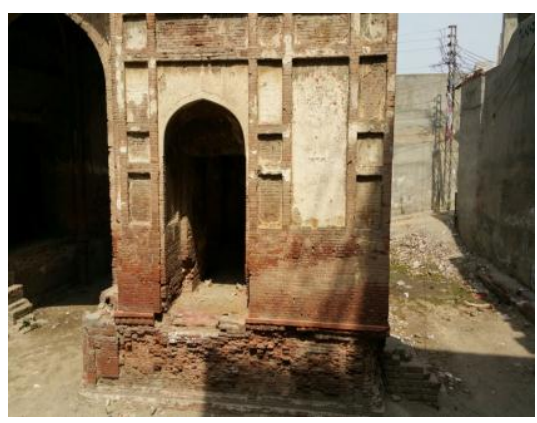

Fig. 10 Massive contour scaling noticed on the front facade

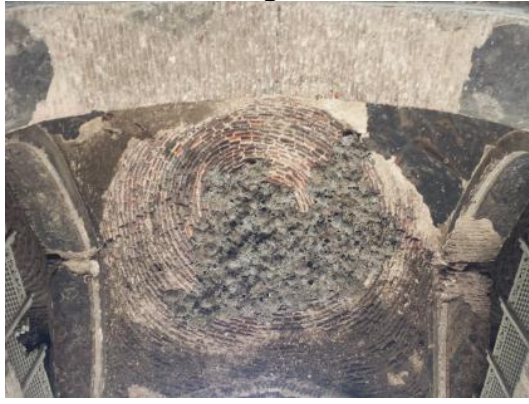

Fig. 11 Scaling seen inside the galib kari

\section{c. Air pollution}

With the increase in the urban population that has resulted into increased motorized movement thus causing more yet massive air pollution that is not environment friendly yet is also the reason of the present building face deserting of this monumental structure. As this tomb and monument structure is 
located near Multan road and a drain passes by. The façade surface of stone work-kashikari has become coarsened and eroded due to pollutants of air. Pollution has also defected the Lime mortar and lime plaster, with the change of calcium carbonate into calcium sulphate, which is water-soluble that has converted into the white powdery finish on the surface thus making the structure very weak. The destructive particulates such as dust, fumes, soot etc. have also stained the exterior with stone work also the fresco work in the entrance chamber.

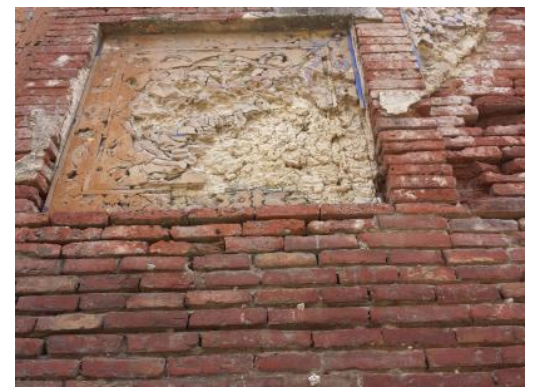

Fig. 12 Defects due to acid rain on the exterior

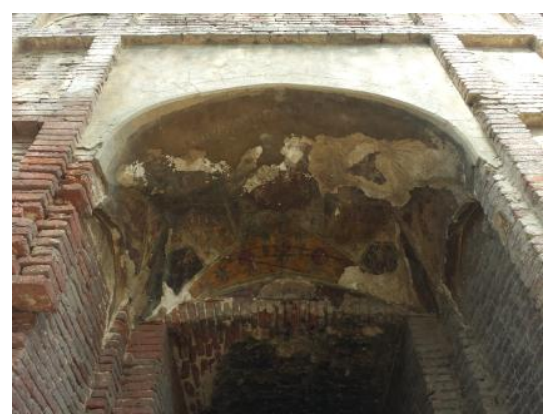

Fig. 13 Defects due to acid rain on the fresco work

\section{d. Tremors}

Heavy tremors generated in the subsoil by heavy traffic via roads and other activities noticed by the squatter settlements in the vicinity have proved to be damaging for this momentous structure. The vibration has also caused loss of foundation strength over the years by affecting its subsoil, and loss of structural strength in super structure as well.

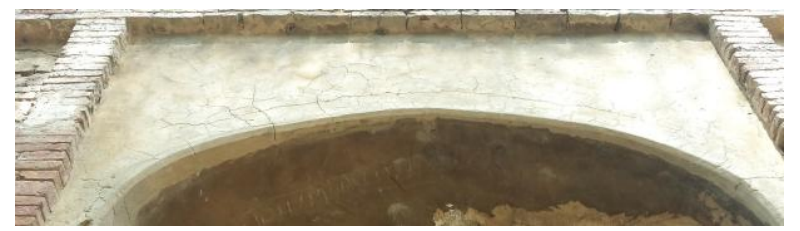

Fig. 14 Cracks in the super structure

\section{e. Vandalism}

Apart from the natural wear and tear as there are no securities checks being provided not even one guard is appointed so all kinds of people can approach the structure apart from just students and visitors. Starting from Rajeet Singh even now many areas have been choked out and sold or there was noticed an attempt of inner fire that caused the inner Ghalib kari that $80 \%$ of the inner chambers on the ground floors are found to be deteriorated . Apart from these animals scrap and feathers are also found attached with the ceilings etc. that might lead to many traces of attempt of illegal activities including theft and black magic as shared by the people of the surroundings.

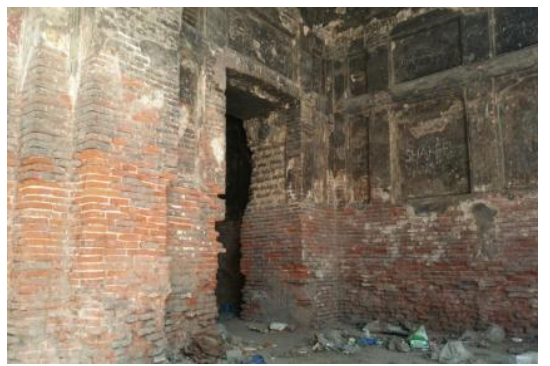

Fig. 15 Damage done in the inner chambers

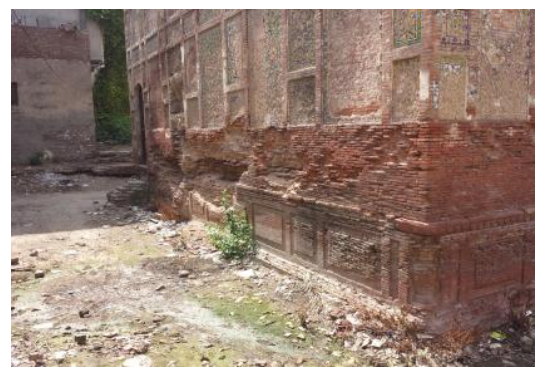

Fig. 16 Damage done in the surrounding of the structure

\section{f. Absence of mature conservation adoption}

The Annual Report of the Archaeological Survey of India 1921-22, compiled by D.Brainerd Spooner, states that at Nawankot, some repairs were commenced and works executed on the 71' outsides of the wall and to the two remaining corner pavilions. But the report also mentioned that much remained to be done at the gateway and pavilions, which were decorated with colored tiles, had for many years been occupied by the villagers as habitations, with the result they had left it them into a bad state of repairs (Report 1921). No mature conservation was continued regarding the restoration work of the monument, causing further damage. No care is also one of the biggest crimes done against these monumental structures.

\section{Deterioration due to organic and fungal causes}

Genetic- corrosion is the change in the nature of the constructional materials due to growth of organic and fungal organisms. This involves mechanism of different kind of degeneration and decomposition processes of the building material. Due to massive flooding and humidity the growth of fungus and algae is very common on the surface of façade materials and end results into disfiguring the original shape and blackening of majority of the surface. This enzymatic action of micro-organisms results in slackening, discoloration cracking and falling of building material from the built structures.

\section{CONCLUSION AND RECOMMENDATION FOR FUTURE RESTORATION PLAN}

A thorough inspection comprised of detailed investigation of interior and exterior materials and condition of the building, its structure is done that reveals that the building is in desperate need of some concern regarding its conservation and restoration and regular maintenance of the built structure. A need for a proper restoration plan should be developed and followed by 
the department of archeology and sponsored by the government including a serious check for the legal action against the encroachments in the surrounding environment of monument as by taking this one measurement might solve many problems this gateway monument is currently facing right now.

The unity of the original building context is very important with the new proposed restoration work for its sustainability, durability and aesthetics of this structure. A team of historian's architects, interior designers, chemists, biologists, engineers is benefactory for a scientific approach for the restoration plan of this structure from the first step. This plan should be preceded by the chemical and physical testing of the building materials that should lead to the prime cause of decay and current situation of the structure itself along with the original context of the materials used then and this may lead to a very calculative analysis. One main drawback highlighted is the lack of academic investigation and any lab testing facility is available here in Pakistan that is why no such quantitative research has ever been done on these parameters for the accurate figures.

This refers to developing an experimental method for restoration and recuperation procedure of historical buildings.

This research brings us down to developing a rational repair scheme that includes firstly the planning the restoration of this built structure that will only be done by serious aim including the tentative cost of the restoration work to be carried out. Secondly the pictorial survey and documentation of the building should be done at regular intervals not just to observe the original context of the used building materials along with any restoration attempt ever done.

All this should be done systematically that would also help us to develop the side by side restoration work done in other historical monuments. Thirdly quantitative analysis of the materials through chemical lab testing that can be done by careful mapping and other computer aided mediums based on conclusions made on visual or pictorial documentation. Developing a timeline of the previous restoration work is also an aided attempt in this regard. All these steps will lead to an accurate restoration plan. Quantitative testing should be done which is of prime importance as they will lead to the experimental testing both chemical or physical lab testing of the materials that helps in building a unity in the previous restoration work done or what should be done next. In this regard sampling of material should be done during the documentation survey of the building which is costly and can lead to a state of misperception when without any funding it won't proceed in the desired manner. Some of these procedures that will be helpful are X-ray diffraction, EDAX (element dispersive analysis), SEM (scanning electronic microscope) etc.

Evaluation should be done based in the result achieved on these experiments and then recommendations should be evaluated. Both these quantitative and qualitative test will provide us with the chemical and physical properties and reactions of different materials thus leading towards recommended methodology and specification of an ideal restoration plan.

In this paper a brief history of one of these neglected monuments has been discussed that are suffering from critical deterioration. An immediate action plan is much needed. Due to the influence of squatter settlements in the surrounding of this monument it is in much threat to lose its original context.as Nawankot monument was taken as a case study so it was deeply studied. Samples are also collected for various Lab testing like microscopy, XRD analysis to further support its restoration plan. This paper may lead to develop a through restoration plan further. Furthermore this derived data may be used to obtain a standard data of the used material in accordance to the time period this structure was built.

\section{ACKNOWLEDGMENT}

A constant support and cooperation of the architectural Programme coordinator Mr.Jahenzaib Ahmed is highly appreciated. Some officials of the Department deserve particular appreciation for their continuous assistance throughout compilation of the research work. Special acknowledgements are due for Senior Architect Tasneem Butt sahib from NCA who provided us with his collected data and the other local residents of Nawankot who continuously assisted and shared all knowledge and experience of the site there.

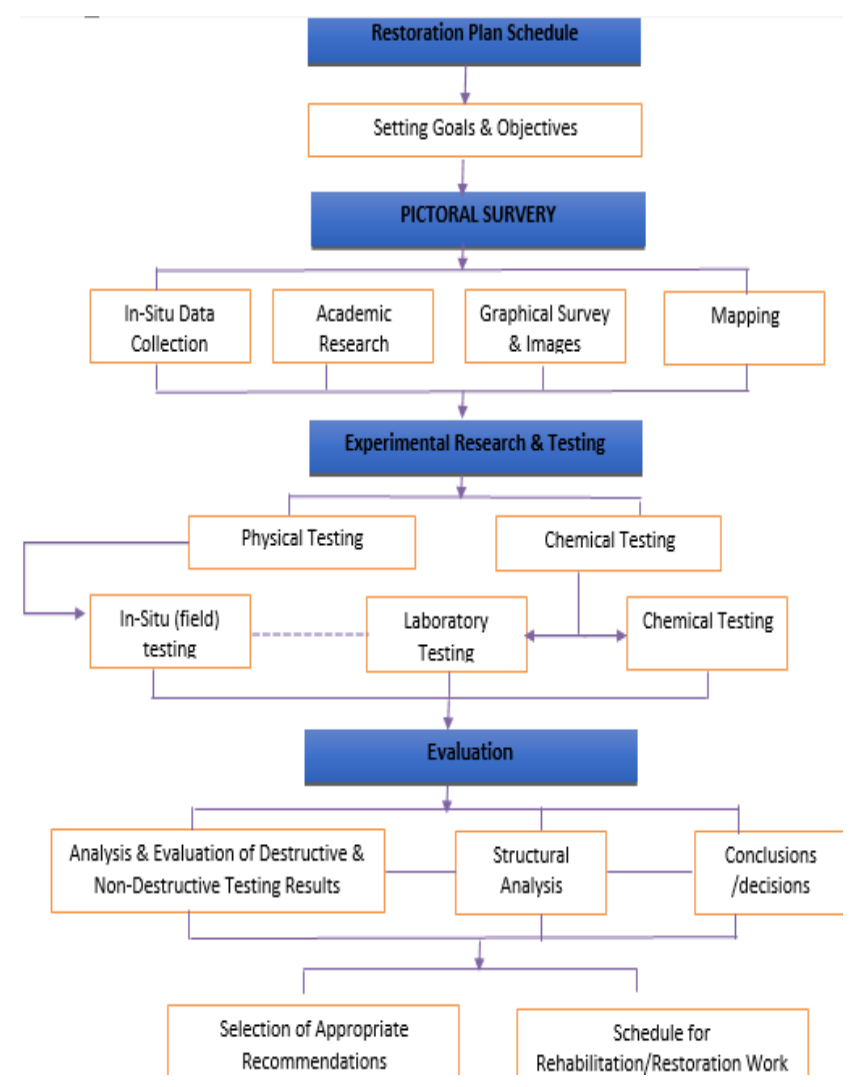

REFERENCES

(Periodical style)

[1] Tasneem butt, "Thesis Report on Nawankot monument ", uet lahore.

[2] Aijazuddin, F.S. Lahore: Illustrated views of the 19th century, Vanguard publishers, Lahore, Pakistan, 23-24 (1991).

[3] S M Latif, Lahore-Architecture Remains, Lahore 1892 Page No 191

[4] Ahmed, Z. Lahore and the Punjab, Sang-e-Meel Publications, Lahore, Pakistan, Vol.1, 115-118, (1982).

[5] UET Research Journal, Pak. J. Engg. \& Appl. Sci. Vol. 2 Jan 2008

[6] K.K.Mumtaz Architecture in Pak5tan-1985, PageNo86 
[7] Awan M. Y.; Ph. D. Thesis, A Study of Significant Historic Buildings in Lahore leading towards the Formulation of a National Conservation Policy for Pakistan, University of Sheffield, UK, (1993), 208-211

[8] Ahmed, Z. Lahore and the Punjab, Sang-e-Meel Publications, Lahore, Pakistan, Vol.1, 115-118, (1982).

[9] Cole, H.H. Preservation of National Monuments, 1 st published by Lemercier \& Co., Paris in 1884, reprinted Oriental press, New Dehli, India, 3-17 (2000).

[10] Croci, G. Conservation and Structural Restoration of Architectural Heritage, Southampton, UK, 112-131 (1998).

[11] Dar, S.R. Historical Gardens of Lahore, Ferozsons Limited, the Mall, Lahore, Pakistan, 9-14, (1982).

[12] Goulding, H. R. Old Lahore Reminiscences of a Resident Lahore, 1924 reprinted by Sind Saqar Printers, Karachi, Pakistan, 51-55 (1996).

[13] Kausar, S. M., Brand, J.L. Wescoat. Shalimar Garden: Landscape, Form and Meaning, Elite publishers, Karachi, Pakistan, 42-45, (1990).

[14] Kausar, S. The Mughal Gardens, Ferozsons, Lahore, Pakistan, 12-19, (1993).

[15] Latif, S. M. Tarikh-e-Punjab (History of Punjab, 1883), republished by Book Talk Publishers, Temple Road, Lahore, Pakistan, 216-218, (2002).

[16] NathH, R. History of Mughal Architecture, Abhinav publications, Delhi, India, 4, 31-39, (1982).

[17] Osborne, W.G. The court and camp of Ranjit Singh (originally printed in 1841), reprinted by Oxford University Press, Karachi, Pakistan, 61-65, (1973).

[18] Weaver, M. and G. Matero. Conseving buildings - guide to techniques and materials. Willy, New York,

[19] Wescoat, J.L. Design of Shalamar Garden, Journal of the Islamic Environmental Design Research Center, II, 85-87, (1986).

(All authors can include biographies with photo at the end of regular papers.)

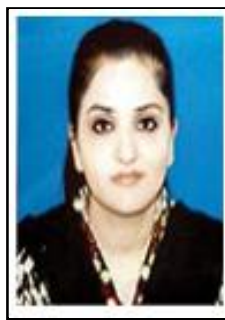

\section{Ayesha Mehmood Malik}

A bonafide faculty member and a Ph.D Scholar at University of Management and Technology Lahore.

Masters in Interior Design from National College of Arts, Lahore. (2009).

Bachelors in Architecture from University of Engineering and Technology Lahore. (2005)

She has 10 years of teaching and field experience in the architectural firms and also as a visiting faculty at various institutions mastering in both subjects of architecture and interior designing.

A distinction holder Ayesha Mehmood Malik has contributed in many universities like National College Of Arts, Lahore, University of Engineering and Technology, Lahore and LSFD, Lahore. She is an executive member of PCATP and IAP, Lahore. Currently working as Assistant Professor in University of Management \& Technology, Lahore, Pakistan. She has conducted several thesis at the bachelor's level in architectural institutes. She is also working as external advisor in various institutes like Lahore College for women university, Lahore. She carries an amazing academic record and aiming to serve better after completing her Phd. Her areas of interest are Interior Designing, Architectural Conservation and heritage and Urban Development etc.

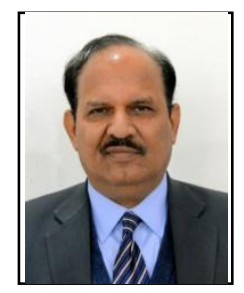

Dr. M.Y. Awan is a Professor and Dean at School of Architecture and Planning, University of Management and Technology, Lahore-Pakistan. He got his Ph.D in Architecture from University of Sheffield, England, United Kingdom.

Dr. Awan has over 40 years of experience in teaching, research and administration. He had earlier served as a Chairman, Coordinator Undergraduate, Director post graduate programs of the Department of Architecture, Chairman Proctorial Board and Advisor Foreign Students at the University of Engineering and Technology, Lahore. $\mathrm{He}$ is $\mathrm{PhD}$ in Architecture from the UK's renowned university of Sheffield. His particular specialization is in Conservation of Architectural and Cultural Heritage. Dr. Awan is a senior member of the Institute of Architects Pakistan (IAP) and served as Honorary Secretary and Vice Chairman of IAP Lahore Chapter. In the year 2010 he played key role as Deputy Convener in organizing the Architecture Students' Jamboree as a part of 14th Asian Congress of Architects (ACA- 14) where students and architects of 17 Asian countries participated. Dr. Awan has supervised more than 500 undergraduate Thesis projects of Bachelor's Degree of Architecture. He has also supervised 31Thesis of Masters of Architecture, 29 at the UET and two at the UMT, that were all successfully completed. Number of Dr. Awan's research publications including postgraduate thesis is 50 .

Dr. Awan joined the UMT as Professor and first Chairman of the newly established Department of Architecture and Planning in September 2012. The Department was under the School of Science and Technology. Dr. Awan contributed in the speedy development of the Department of Architecture and its program of Bachelor of Architecture. Under his academic leadership the program was granted NOC by the PCATP within shortest time period. Under his academic leadership another program of BS in City and Regional Planning was successfully launched from the Fall Semester 2014. He had also launched postgraduate programs of Master of Architecture (M. Arch), M. Arch. with Specialization in Architectural Conservation, M. Arch. with Specialization in Urban Design and $\mathrm{PhD}$ in Architecture from the Fall Semester 2013.

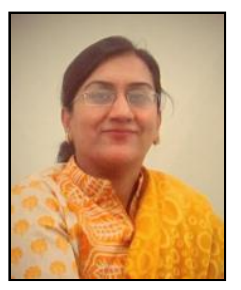

Memoona Rashid

Place: Lahore, Pakistan Date of Birth: $15^{\text {th }}$ March, 1982 Master s Student University of Management and Technology Lahore. Bachelors in Architecture from University of Engineering and Technology Lahore. (2006)

Worked in Superior University Lahore (August 2014 till June 2015). Worked in University of South Asia Lahore (June 2009-June 2014). Currently working as Assistant Professor in University of Management \& Technology, Lahore, Pakistan. 